\title{
New species of Synodontella (Monogenea, Ancyrocephalidae) gill parasites of two Synodontis spp. (Pisces, Mochokidae) from the Boumba River (Congo Basin, East Cameroon)
}

\author{
Jonathan A. Mbondo ${ }^{1,2}$, Jacques Nack $^{3}$, Arnold R. Bitja Nyom ${ }^{4,5}$, Antoine Pariselle ${ }^{6,7, *}$, and Charles F. Bilong Bilong ${ }^{1}$ \\ ${ }^{1}$ University of Yaoundé 1, Laboratory of Parasitology and Ecology, PO Box 812, Yaoundé, Cameroon \\ ${ }^{2}$ Specialized Research Center for Marine Ecosystems, IRAD, PO Box 219, Kribi, Cameroon \\ 3 University of Douala, Laboratory of Parasitology and Ecology, PO Box 24157, Douala, Cameroon \\ ${ }^{4}$ Institute of Fisheries and Aquatic Sciences of Yabassi (ISH), University of Douala, Cameroon \\ ${ }^{5}$ Department of Biological Sciences, the University of Ngaoundéré, PO Box 454, Ngaoundéré, Cameroon \\ ${ }^{6}$ ISEM, Univ. Montpellier, CNRS, IRD, Montpellier, France \\ 7 Faculty of Sciences, Laboratory "Biodiversity, Ecology and Genome", Research Center "Plant and Microbial Biotechnology, \\ Biodiversity and Environment", Mohammed V University in Rabat, Morocco
}

Received 22 February 2019, Accepted 29 May 2019, Published online 27 June 2019

\begin{abstract}
Three new species of Synodontella Dossou \& Euzet, 1993 are described from two species of Synodontis (Mochokidae) collected from the middle course of the Boumba River (East Cameroon): Synodontella angustupenis n. sp. from Synodontis nummifer, Synodontella longipenis n. sp. and Synodontella simplex n. sp. from Synodontis decorus. These new species are different from the other Synodontella species already described due to their horseshoe-shaped dorsal transverse bars. Synodontella angustupenis differs from S. longipenis and S. simplex by the morphology of its penis, a thin tube, and its accessory piece, bifid at its extremity. Synodontella longipenis differs from the other two species by the morphology and the size of its male copulatory organ, which is very long. Synodontella simplex differs from $S$. angustupenis and $S$. longipenis by the shape of its penis, which is simple, and of its accessory piece, with a developed heel. The difference between the dorsal transverse bars of Synodontella species from the Sanaga River in Cameroon (and other localities in Africa), slightly curved, and those from the Boumba River, horseshoe-shaped, makes it possible to separate Synodontella species into two different subgroups. This difference can be explained by a long isolation period of the hosts, living in different river basins, followed by the divergence of the parasite populations (vicariant speciation).
\end{abstract}

Key words: Synodontella angustupenis n. sp., Synodontella simplex n. sp., Synodontella longipenis n. sp., Synodontis, Siluriformes, Africa.

\begin{abstract}
Résumé - Trois nouvelles espèces de Synodontella (Monogenea, Ancyrocephalidae), parasites des branchies de deux espèces de Synodontis (Pisces, Mochokidae) de la rivière Boumba (bassin du Congo, Est Cameroun). Trois nouvelles espèces de Synodontella Dossou \& Euzet, 1993 sont décrites chez deux espèces de Synodontis (Mochokidae) collectées dans le cours moyen de la rivière Boumba (Est Cameroun) : Synodontella angustupenis n. sp. de Synodontis nummifer, Synodontella longipenis n. sp. et Synodontella simplex n. sp. de Synodontis decorus. Ces nouvelles espèces sont différentes des autres espèces de Synodontella déjà décrites par leurs barres transversales dorsales en forme de fer à cheval. Synodontella angustupenis diffère de S. longipenis et de $S$. simplex par la morphologie de son pénis, un tube fin et de sa pièce accessoire, bifide à son extrémité. Synodontella longipenis diffère des deux autres espèces par la morphologie et la taille de son organe copulateur mâle, qui est très long. Synodontella simplex se distingue de $S$. angustupenis et $S$. longipenis par la forme de son pénis, qui est simple, et de sa pièce accessoire, avec un talon développé. La différence entre les barres transversales dorsales des espèces de Synodontella du fleuve Sanaga au Cameroun (et d'autres localités africaines), légèrement incurvées, et celles de la rivière Boumba, en forme de fer à cheval, permet de séparer les espèces de Synodontella en deux sous-groupes différents. Cette différence peut être expliquée par une longue période d'isolement des hôtes, vivant dans différents bassins hydrographiques, suivie de la divergence des populations de parasites (spéciation vicariante).
\end{abstract}

*Corresponding author: antoine.pariselle@ird. fr

This is an Open Access article distributed under the terms of the Creative Commons Attribution License (http://creativecommons.org/licenses/by/4.0), which permits unrestricted use, distribution, and reproduction in any medium, provided the original work is properly cited. 


\section{Introduction}

The high incidence of fish diseases remains a major constraint for the successful economic development of cultured species, and ectoparasites such as monogeneans are probably the cause of such pathologies [16]. Members of the catfish family Mochokidae are amongst the most important teleost species suitable for aquaculture, and species of Synodontis Cuvier, 1817 are of great commercial importance in Africa [7]. Taking advantage of a sampling campaign for the study of the Congo basin's fish species in the East Region of Cameroon, we examined Synodontis species; among the 51 valid species reported, 48 are endemic [3], but their culture potential or parasitic fauna are not well known. Gill filaments of the two local sampled species were studied for their specific monogenean parasites belonging to Synodontella Dossou \& Euzet, 1993 [4]. The type species of this genus, Synodontella synodontii (Paperna \& Thurston, 1968), had been assigned and later reassigned to different ancyrocephalid genera, Ancyrocephalus Creplin, 1839, then Schilbetrema Paperna \& Thurston, 1968 [4]. However, this species presents unusual morphological characteristics by having a ventral anchor with a hull and a welded central protuberance of the ventral bar; thus, Dossou and Euzet [4] proposed the genus Synodontella to include monogeneans with these features. The morphology of the haptoral sclerites of Synodontella spp. is close to that of two other ancyrocephalid genera: Schilbetrema by the shape of the ventral and dorsal anchors and by having a central protuberance on the ventral bar; Protoancylodiscoides by the morphology of the ventral anchors with a hull. The first molecular data on Synodontella have shown that this taxon is closer to Schilbetrema than to the other dactylogyrid genera parasitizing catfishes, namely Quadriacanthus Paperna, 1961, Thaparocleidus Jain, 1952 or Pseudancylodiscoides Yamaguti, 1963 [13]. To date, only seven species of Synodontella have been reported, all from Africa, i.e.: Synodontella synodontii [12] described from the gills of Synodontis victoriae Boulenger, 1906; Synodontella arcopenis Dossou \& Euzet, 1993 [4] from Synodontis sorex Günther, 1864; Synodontella melanoptera Dossou \& Euzet, 1993 [4] from Synodontis melanopterus Boulenger, 1902; Synodontella davidi Dossou \& Euzet, 1993 [4] from Synodontis membranaceus (Geoffroy St Hilaire, 1809); Synodontella zambezensis Douëllou \& Chishawa, 1995 [5] from Synodontis zambezensis Peters, 1852; Synodontella apertipenis Mbondo, Nack \& Pariselle, 2017 [11] and Synodontella sanagaensis Mbondo, Nack \& Pariselle, 2017 [11] from Synodontis rebeli Holly, 1926. The present parasitological survey on Synodontis spp. provides three new species of Synodontella described herein. The diversification of Cameroonian Synodontella species is also discussed.

\section{Materials and methods}

Fish specimens (5 Synodontis nummifer Boulenger, 1899, 132-174 mm SL; and $9 \mathrm{~S}$. decorus Boulenger, 1899, $125-246 \mathrm{~mm}$ SL) were caught (02/2017) by angling from the middle course of the Boumba River near Mang-kaka $\left[3^{\circ} 18^{\prime} 42.89^{\prime \prime} \mathrm{N} 14^{\circ} 04^{\prime} 43.19^{\prime \prime} \mathrm{E}\right.$ (see Fig. 1)]. Fishes, euthanized

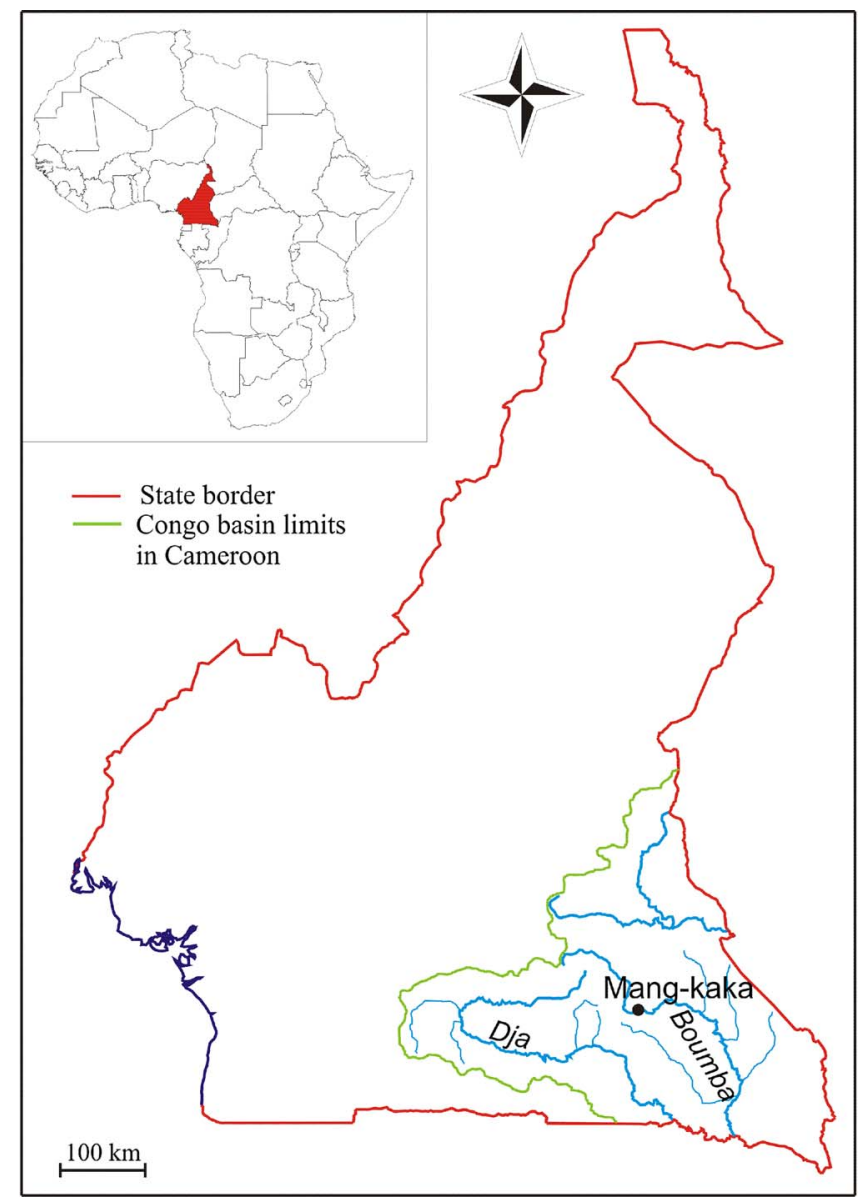

Figure 1. Map of the Boumba River with sampling locality.

by severing their dorsal spine, were dissected on site; gill arches were removed by dorsal and ventral sections, and then placed in a Petri-dish containing tap water. Monogeneans were dislodged from the gill filaments with the aid of a dissecting needle and were mounted between slide and cover slip in a drop of glycerin ammonium-picrate (GAP) mixture [10]. Preparations were sealed using Glyceel [1] and returned to the Laboratory of Parasitology and Ecology of the University of Yaoundé I for further laboratory analyses. Morphological description and measurements of the sclerotized pieces of the haptor and the male copulatory organ (MCO) were carried out according to Dossou \& Euzet (1993) using a Leica DM2500 microscope and LAS 3.8 software. Drawings of the sclerotized pieces were carried out using Coral Draw X4 Software (Ver 14.0.0.701; Corel Corporation, www.corel.com). Type specimens were deposited at the Royal Museum for Central Africa (RMCA, Tervuren) and at the Muséum National d'Histoire Naturelle (MNHN, Paris).

\section{Results}

The general appearance of all the species described corresponds to the diagnosis of Synodontella given by Dossou \& Euzet (1993). 
Table 1. Measurements of the three new species (in $\mu$ m: mean (minimum-maximum)).

\begin{tabular}{|c|c|c|c|}
\hline Specific names & Synodontella angustupenis $\mathrm{n} . \mathrm{sp}$. & Synodontella longipenis $\mathrm{n} . \mathrm{sp}$. & Synodontella simplex $\mathrm{n} . \mathrm{sp}$. \\
\hline Number of specimens & 12 & 07 & 22 \\
\hline Total length & $618.2(485.7-743)$ & $1024.6(508.7-1304.9)$ & $801.9(591.3-1146.7)$ \\
\hline Width & $123(108.1-147.2)$ & $164.8(146.3-194.7)$ & $123.4(92-163.3)$ \\
\hline \multicolumn{4}{|l|}{ Dorsal anchor } \\
\hline a & $48.4(45.2-50.4)$ & $64.9(63.6-66.5)$ & $56.2(54.1-58.7)$ \\
\hline $\mathrm{b}$ & $38.4(37.4-40)$ & $54.6(52-56.2)$ & $46.2(43.2-48.5)$ \\
\hline $\mathrm{c}$ & $3.6(3.2-4.1)$ & $5.1(4.3-6.1)$ & $3.9(3-4.5)$ \\
\hline $\mathrm{d}$ & $15.5(15-16.3)$ & $17.6(16.9-18.4)$ & $17.1(14.9-18.4)$ \\
\hline $\mathrm{e}$ & $16.8(16.2-18.6)$ & $18.9(18.1-20)$ & $18.3(17-19.8)$ \\
\hline \multicolumn{4}{|l|}{ Dorsal bar } \\
\hline $\mathrm{x}$ & $35.3(33.8-36.6)$ & $47.4(45.5-48.9)$ & $53.3(50-55.8)$ \\
\hline $\mathrm{w}$ & $4.8(4.4-5.2)$ & $8.4(7.8-8.7)$ & $7.8(6.8-9.3)$ \\
\hline \multicolumn{4}{|l|}{ Ventral anchor } \\
\hline $\mathrm{a}$ & $25.1(23.4-26.9)$ & $46.9(45.2-47.6)$ & $42.8(40.7-44.4)$ \\
\hline $\mathrm{b}$ & $28(26.2-29.7)$ & $39.3(38.6-39.7)$ & $35.6(32.4-38.3)$ \\
\hline $\mathrm{c}$ & $6.2(5.5-6.9)$ & $8.1(7.3-8.7)$ & $8.5(7.6-9.4)$ \\
\hline $\mathrm{d}$ & $14.7(14.2-15.6)$ & $16.3(14.4-17.4)$ & $14.3(12.3-16.1)$ \\
\hline $\mathrm{e}$ & $22.7(21.4-24.2)$ & $29.2(28-29.7)$ & $25.9(23.1-27.9)$ \\
\hline \multicolumn{4}{|l|}{ Ventral bar } \\
\hline $\mathrm{x}$ & $29.9(28.4-32.6)$ & $47.3(46.4-48.1)$ & $54.4(51.2-57.5)$ \\
\hline $\mathrm{w}$ & $5.4(4.2-6.3)$ & $7(6.5-7.5)$ & $8.8(6-10.1)$ \\
\hline $\mathrm{h}$ & $8.7(8-9.3)$ & $11.7(10.2-13)$ & $11.9(10-13.5)$ \\
\hline \multicolumn{4}{|l|}{ Male copulatory organ } \\
\hline $\mathrm{Pe}$ & $45.8(42.2-57.5)$ & $162.9(160.6-165.7)$ & $49.7(47.2-52.9)$ \\
\hline Ap & $24.1(22.2-27.5)$ & $85(82.3-86.6)$ & $65.4(62-69.3)$ \\
\hline
\end{tabular}

\section{Synodontella angustupenis Mbondo, Nack \& Pariselle n. sp.}

urn:1sid:zoobank.org:act:29D5F9CE-8907-4A65-9E0A3D531BF065F7

Type host: Synodontis nummifer Boulenger, 1899.

Site: Gills.

Type-locality: Mang-kaka, Cameroon $\left(3^{\circ} 18^{\prime} 42.89^{\prime \prime} \mathrm{N} 14^{\circ}\right.$ $\left.04^{\prime} 43.19^{\prime \prime} \mathrm{E}\right)$.

Prevalence: $80 \%$.

Mean intensity: 4.6.

Material: Twelve whole-mounted specimens in GAP solution.

Type specimens: Holotype: RMCA No. M.T. 38597; Paratypes: RMCA No. M.T.38598-38599, MNHN HEL1020HEL1021.

Etymology: The specific epithet (an adjective) is from Latin $($ Angustus $=$ small + penis $=$ penis $)$ and refers to the small size of the MCO of the members of this species.

Note: The authors of the new taxon are different from the authors of this paper; Article 50.1 and Recommendation 50A of International Code of Zoological Nomenclature [9].

Description (Table 1, Fig. 2): Body flattened dorsoventrally; length 485.7-743; width 108.1-147.2. Two pairs of eye-spots of equal size, anterior to pharynx. Haptor with two pairs of anchors; dorsal ones larger with base sabot-shaped and reduced shaft. Dorsal bar horseshoe-shaped. Ventral anchors with a developed guard; diagonal hull with thin sclerotized filament at posterior end. Ventral transverse bar with central posterior protuberance; two lateral arms with enlarged ends. Seven pairs of small hooks, approximatively equal in size, and retained larval appearance. The male copulatory organ bow shaped; thin tubular penis; accessory piece straight, welded to the base of the penis and bifid at the extremity.

Remarks: Synodontella angustupenis n. sp. differs from all other known Synodontella spp. by the shape of the dorsal transverse bar (horseshoe-shaped) and of its accessory piece (straight and bifid at its distal extremity).

\section{Synodontella longipenis Mbondo, Nack \& Pariselle n. sp.}

urn:Isid:zoobank.org:act:998B238D-CEDC-4590-906BDBE743D4DE3B

Type host: Synodontis decorus Boulenger, 1899.

Site: Gills.

Type-locality: Mang-kaka, Cameroon $\left(3^{\circ} 18^{\prime} 42.89^{\prime \prime} \mathrm{N} 14^{\circ}\right.$ $\left.04^{\prime} 43.19^{\prime \prime} \mathrm{E}\right)$.

Prevalence: $22.2 \%$.

Mean intensity: 0.55 .

Material: Seven whole-mounted specimens in GAP solution.

Type specimens: Holotype: RMCA No. M.T. 38592; Paratypes: RMCA No. M.T. 38593-98594, MNHN HEL1022-HEL1023.

Etymology: The specific name is from Latin (longi $(s)=$ long + penis $=$ penis) and refers to the great length of the MCO.

Note: The authors of the new taxon are different from the authors of this paper; Article 50.1 and Recommendation 50A of International Code of Zoological Nomenclature [9].

Description (Table 1, Fig. 3): Body flattened dorsoventrally; length 508.7-1304.9; width 146.3-194.7. Two pairs 


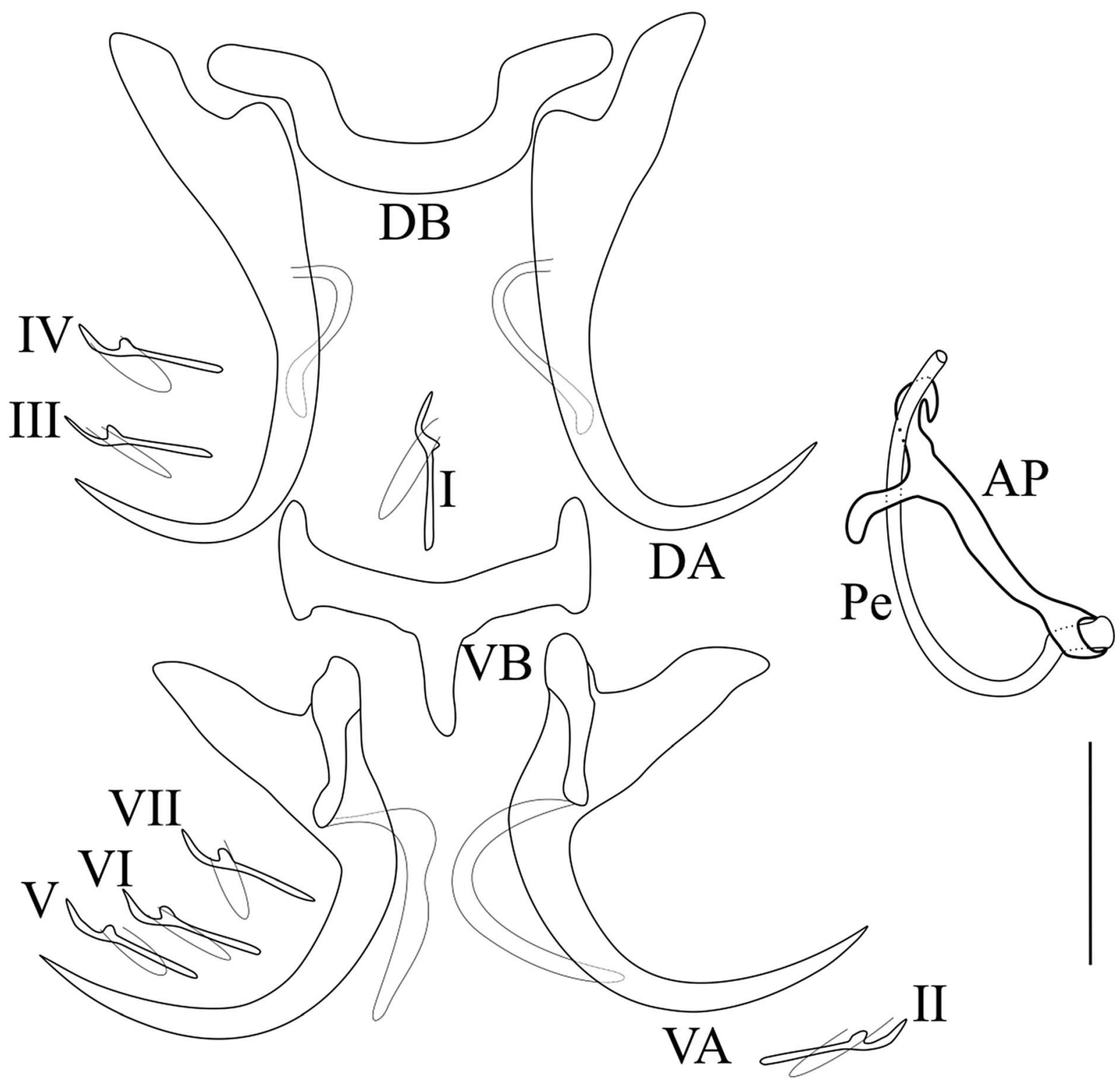

Figure 2. Sclerotized parts of Synodontella angustupenis n. sp. Scale bar $=20 \mu \mathrm{m}$. AP, accessory piece; DA, dorsal anchor; DB, dorsal bar; VA, ventral anchor; VB, ventral bar; Pe, penis; I-VII, hooks.

of eye-spots, anterior to pharynx, of equal size. Haptor separated from the rest of the body by a narrow constriction and made up of two pairs of anchors. Dorsal anchors with long blade, bent at third; shaft rudimentary; thin sclerotized filaments present. Dorsal bar horseshoe-shaped. Ventral anchors smaller than dorsal ones; hull with a thin sclerotized filament at posterior end. Ventral bar with central protuberance crowned by a cuticular structure and enlarged ends. 14 small hooks, approximatively equal in size and retained larval appearance. The male copulatory organ consisting of a long copulatory tube (penis), curved at proximal part and folded at $90^{\circ}$ at distal extremity; and a well sclerotized bifid accessory piece, with one long and one short arm, folded around the basal extremity of the penis, both ending hook-shaped.

Remarks: Synodontella longipenis is close to Synodontella davidi by the morphology of the MCO, in both species the penis is a long curved tube; the accessory piece is also long and welded around the penis base. Synodontella longipenis differs from $S$. davidi by the size of the penis (163 vs. 120) and by having a dorsal bar horseshoe-shaped and the central protuberance of the ventral bar crowned by a cuticular structure. Synodontella longipenis resembles $S$. angustupenis by having a dorsal bar horseshoe-shaped, but differs by having a much longer penis and accessory piece (163 vs. 46 and 85 vs. 24, respectively) and a ventral bar central protuberance crowned by a cuticular structure.

\section{Synodontella simplex Mbondo, Nack \& Pariselle} n. sp.

urn:Isid:zoobank.org:act:DBB06616-9935-4447-8602FEBB1ABCBFB3

Type host: Synodontis decorus Boulenger, 1899. 


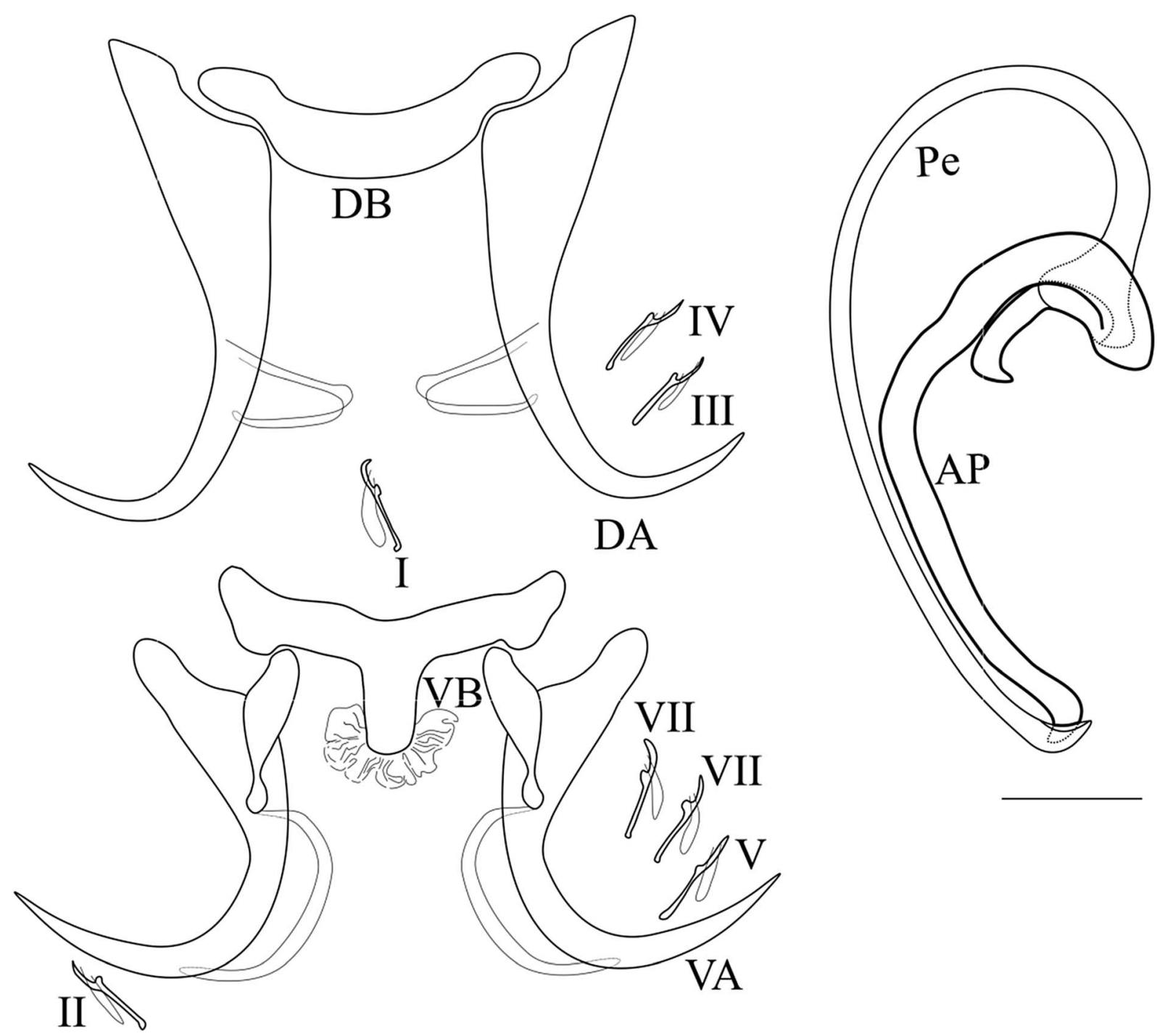

Figure 3. Sclerotized parts of Synodontella longipenis $\mathrm{n}$. sp. Scale bar $=20 \mu \mathrm{m}$. AP, accessory piece; DA, dorsal anchor; DB, dorsal bar; VA, ventral anchor; VB, ventral bar; Pe, penis; I-VII, hooks.

Site: Gills

Type-locality: Mang-kaka, Cameroon $\left(3^{\circ} 18^{\prime} 42.89^{\prime \prime} \mathrm{N} 14^{\circ}\right.$ $\left.04^{\prime} 43.19^{\prime \prime} \mathrm{E}\right)$

Prevalence: $66.6 \%$

Mean intensity: 2.4

Material: twenty-two whole-mounted specimens in GAP solution.

Type specimens: Holotype: RMCA No. M.T.38596, Paratypes: RMCA No. M.T. 38595, MNHN HEL1022-HEL1023.

Etymology: The specific name is from Latin (simplex $=$ simple) and refers to the simple shape of the MCO.

Note: The authors of the new taxon are different from the authors of this paper; Article 50.1 and Recommendation 50A of International Code of Zoological Nomenclature [9].

Description (Table 1, Fig. 4): Body flattened dorsoventrally; length 591.3-1146.7; width 92-163.3; two pairs of eye-spots, anterior to the pharynx and of equal size. Haptor separate of the rest of the body by a narrow constriction and made up of two pairs of anchors. Dorsal anchors with base enlarged, small and slightly sclerotized filament present; reduced shaft. Dorsal bar horseshoe-shaped. Ventral anchors smaller than dorsal ones, developed guard, hull with slightly sclerotized filament at distal end. Ventral bar with central protuberance and lateral arms with spanner-shaped ends. Fourteen (14) small hooks, approximatively equal in size and retain larval appearance. The male copulatory organ made up of a simple penis with slightly flared base and narrowed at distal end; well sclerotized accessory piece, longer than the penis and bifurcated at distal extremity; proximal heel present and well developed.

Remarks: Synodontella simplex n. sp. differs from all other known Synodontella spp. by the morphology of the MCO made up of a simple penis, slightly flared at the base (with no visible bulb), and a well sclerotized accessory piece, longer than the penis, with a bifid distal end and a developed heel at the proximal extremity; this MCO morphology had never been observed before in Synodontella spp. 


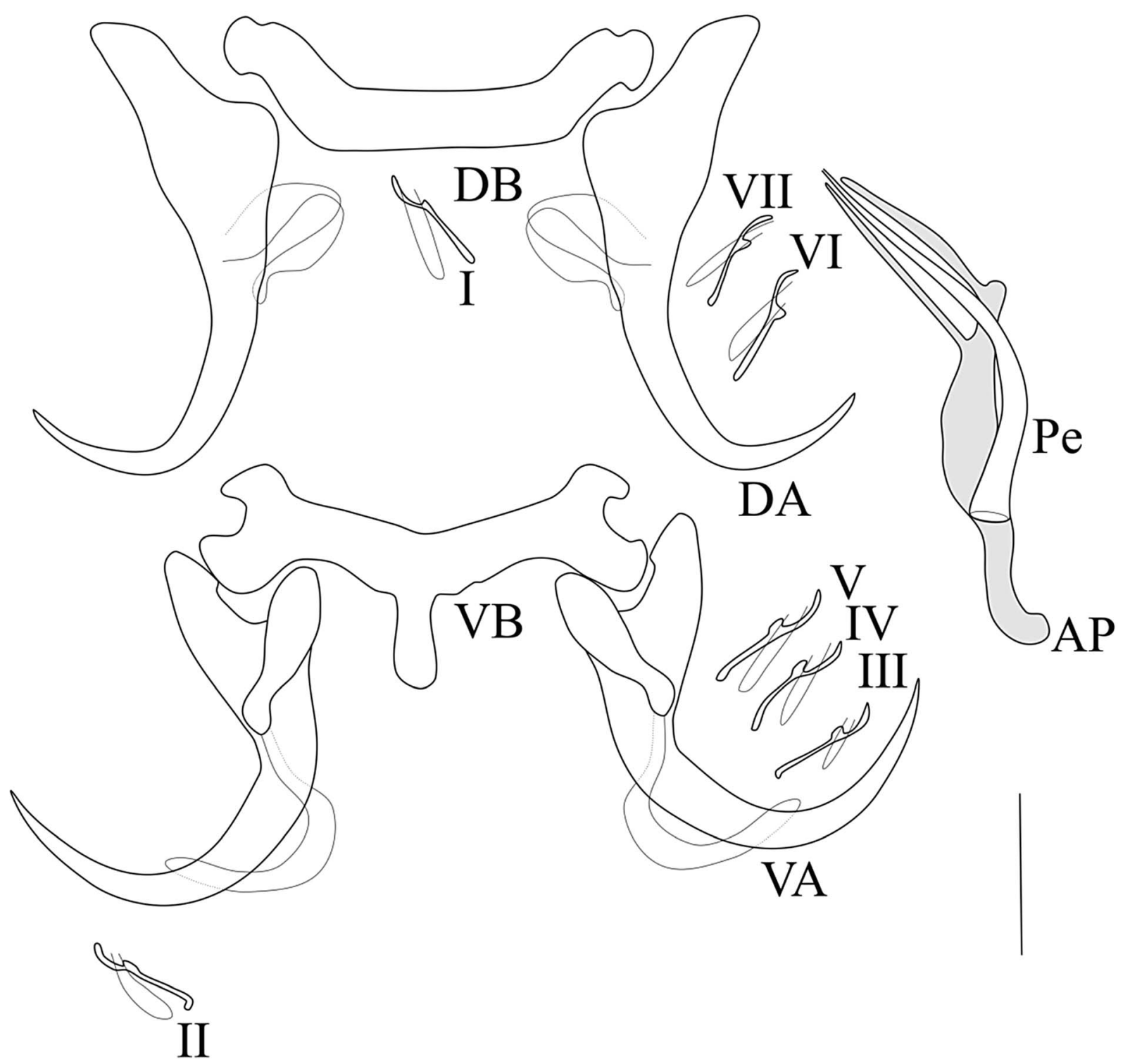

Figure 4. Sclerotized parts of Synodontella simplex n. sp. Scale bar $=20 \mu \mathrm{m}$. AP, accessory piece; DA, dorsal anchor; DB, dorsal bar; VA, ventral anchor; VB, ventral bar; Pe, penis; I-VII, hooks.

\section{Discussion}

Three new species are described in this study, resulting in a total of 10 species of Synodontella described on the gills of Synodontis fishes, all being oioxenous [6] toward their hosts. Synodontella angustupenis n. sp., S. longipenis n. sp. and S. simplex $\mathrm{n}$. sp. appear to form a complex of morphologically related species characterized by having a horseshoe-shaped dorsal bar. To date, known Cameroonian Synodontella species can be divided in two subgroups (see Fig. 5). The first one includes Synodontella species with the dorsal bar slightly curved, parasites of Synodontis spp. from the Sanaga River (Low Guinea Forest Basin) (S. apertipenis, S. sanagaensis and $S$. melanoptera) [11]. The second subgroup is made up of the three new species of Synodontella described herein with a horseshoe-shaped dorsal bar, parasites of Synodontis spp. from Boumba River (Congo Basin). It is suggested that the difference between these monogenean species could result from the geographical isolation of the populations (hosts and parasites) from the Sanaga and Boumba systems. An ancestral host species through time could have fragmented into relatively large and isolated populations followed by lineage divergence of both parasite and host populations $[2,8]$ with the formation of allopatric descendant species. In this case, the present observation may serve as evidence for the existence of two or more genetic lineages within the genus Synodontella. A slightly curved dorsal bar is also present in $S$. arcopenis from the Ouémé (Benin), S. davidi from the Niger (Mali) and $S$. zambezensis (Zambia) (S. synodontii having a V-shaped dorsal bar). Therefore, the shape of the dorsal bar does not appear to be related to the geography of the hosts or parasites (Fig. 6), but the authors emphasize the potential importance of the dorsal bar in the classification of species of Synodontella, especially as host specificity imposes morphological adaptation 


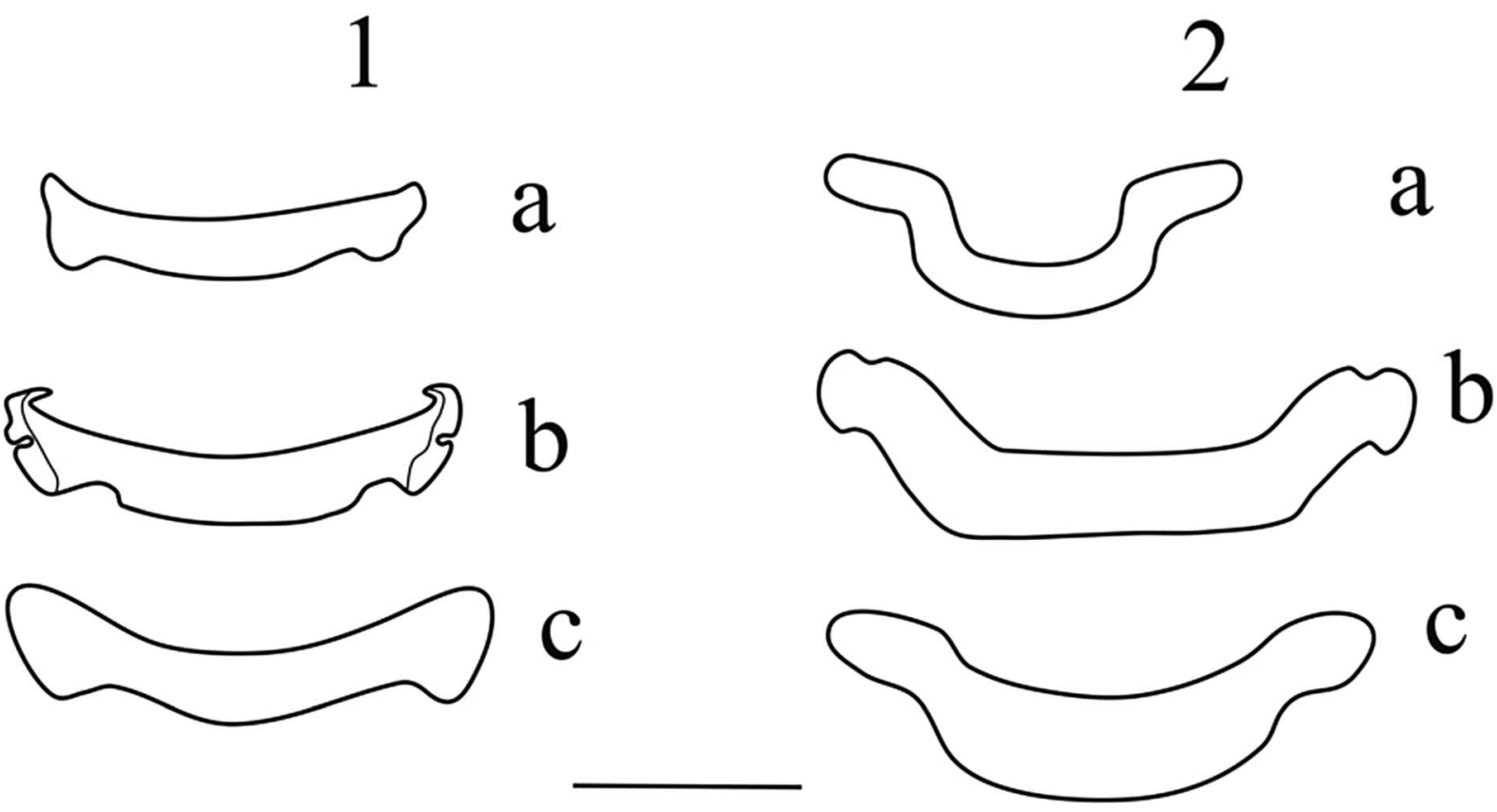

Figure 5. Comparison of the dorsal bar shapes of Synodontella species from the Sanaga River (1) and from the Boumba River (2). 1.a, Synodontella melanoptera; 1.b, Synodontella apertipenis; 1.c, Synodontella sanagaensis; 2.a, Synodontella angustupenis n. sp.; 2.b, Synodontella simplex n. sp.; 2.c, Synodontella longipenis n. sp. Scale bar $=20 \mu \mathrm{m}$.

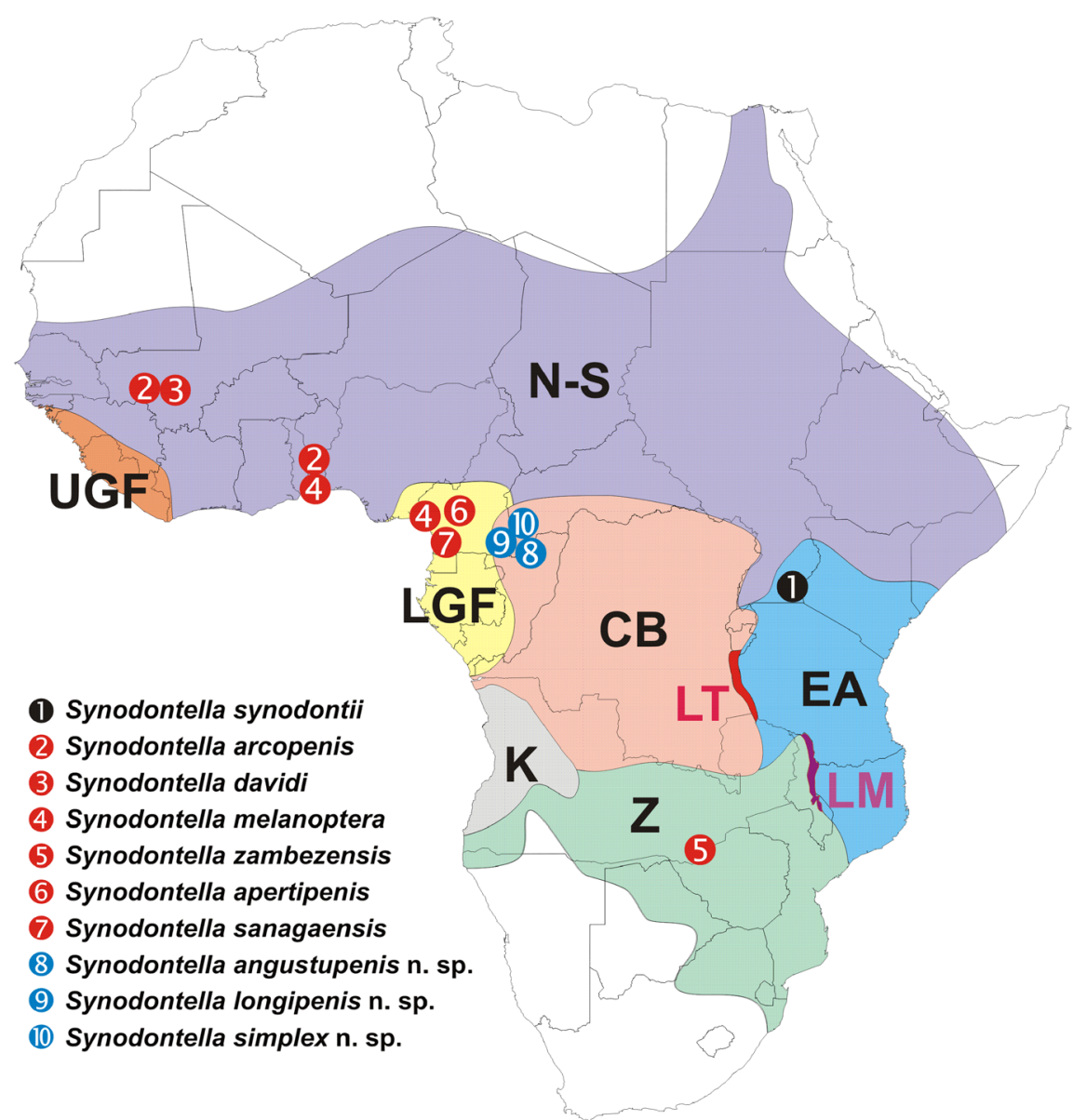

Figure 6. Map showing the major ichthyological provinces of Africa [Nilo-Sudan (N-S), Upper Guinea Forest (UGF), Lower Guinea Forest (LGF), Congo Basin (CB), Quanza (K), Zambezi (Z), East Africa (EA), Lake Tangayika (LT) and Lake Malawi (LM)], with the type localities of described Synodontella spp. (in blue: species with horseshoe-shaped dorsal bars) (modified after [14]). 
of the attachment organs of parasites found on phylogenetically related hosts. In addition, the degree of host specificity is correlated with the morphological attributes of the parasite attachment organ [15], and thus may explain parasite diversification.

Acknowledgements. Many thanks to Drs. Dieu ne dort Bahanak, Etienne Didier Bassock Bayiha and Mr. John Francis Akoumba from the Faculty of Sciences of the University of Yaoundé I for their help in fieldwork and manuscript writing. We also thank the anonymous referees for valuable comments and suggestions.

\section{References}

1. Bates JW. 1997. The slide-sealing compound "Glyceel". Journal of Nematology, 29, 565-566.

2. Brooks DR, McLennan DA. 1991. Cospeciation, in Phylogeny, Ecology and Behavior, Brooks DR, McLennan DA, Editors. The University of Chicago Press: Chicago and London. p. 205-275.

3. Danadu MC. 2014. Problématique de Synodontis Cuvier, 1816 (Siluriformes, Mochokidae) dans le bassin du fleuve Congo: systématique et écologie (R.D.C.). Thèse, Université de Kisangani, 230, p.

4. Dossou C, Euzet L. 1993. Synodontella n. g. (Monogenea, Ancyrocephalidae) parasites de Mochokidae africains du genre Synodontis Cuvier, 1817. Journal of African Zoology, 107, 175-185.

5. Douëllou L, Chishawa AMM. 1995. Monogeneans of three Siluriform fish species in Lake Kariba, Zimbabwe. Journal of African Zoology, 109, 99-115.

6. Euzet L, Combes C. 1980. Les problèmes de l'espèce chez les animaux parasites. Mémoires de la Société Zoologique de France, 40, 239-285.

7. Friel JP, Vigliotta TR. 2006. Synodontis acanthoperca, a new species from the Ogôoué River system, Gabon with comments on spiny ornamentation and sexual dimorphism in mochokid catfishes (Siluriformes: Mochokidae). Zootaxa, 1125, 45-56.

8. Huyse T. 2002. Evolutionary associations between Gyrodactylus and its goby host: bound forever. Thesis, Katholieke Universiteit Leuven. p. 193.

9. ICZN. 1999. International Code of Zoological Nomenclature. The International Trust for Zoological Nomenclature: London, http://www.nhm.ac.uk/hosted-sites/iczn/code/.

10. Malmberg G. 1957. On the occurrence of Gyrodactylus on Swedish fishes. Skrifter Utgivna av Sodra Sveriges Fiskeriforening Arsskrift, 1956, 19-76 (In Swedish with English abstract and species descriptions).

11. Mbondo JA, Nack J, Pariselle A, Bilong Bilong CF. 2017. The diversity of monogenean gill parasites of two Synodontis species (Siluriformes, Mochokidae) with the description of two new species assigned to Synodontella. Vie et Milieu, 67, 75-80.

12. Paperna I, Thurston JP. 1968. Monogenic Trematodes (Dactylogyridae) from fish in Uganda. Revue de Zoologie et de Botanique Africaine, 78, 284-294.

13. Raphahlelo ME, Přikrylová I, Matla MM, Theron J, LuusPowell WJ. 2016. A revised description of Synodontella zambezensis Douëllou et Chishawa, 1995 (Monogenea: Ancyrocephalidae) from the gills of Synodontis zambezensis (Siluriformes: Mochokidae) from South Africa. Helminthologia, 53, 363-371.

14. Roberts TR. 1975. Geographical distribution of African freshwater fishes. Zoological Journal of the Linnean Society, 57, 249-319.

15. Šimková A, Verneau O, Gelnar M, Morand S. 2006. Specificity and specialization of congeneric monogeneans parasitizing cyprinid fish. Evolution, 60, 1023-1037.

16. Tombi J, Bilong Bilong CF. 2004. Distribution of gill parasites of the freshwater fish Barbus martorelli Roman, 1971 (Teleostei: Cyprinidae) and tendency to inverse intensity evolution between Myxosporidia and Monogenea as a function of the host age. Revue d'Élevage et de Médecine Vétérinaire des Pays Tropicaux, 57, 71-76.

Cite this article as: Mbondo JA, Nack J, Bitja Nyom AR, Pariselle A \& Bilong Bilong CF. 2019. New species of Synodontella (Monogenea, Ancyrocephalidae) gill parasites of two Synodontis spp. (Pisces, Mochokidae) from the Boumba River (Congo Basin, East Cameroon). Parasite 26, 37.

Reviews, articles and short notes may be submitted. Fields include, but are not limited to: general, medical and veterinary parasitology; morphology, including ultrastructure; parasite systematics, including entomology, acarology, helminthology and protistology, and molecular analyses; molecular biology and biochemistry; immunology of parasitic diseases; host-parasite relationships; ecology and life history of parasites; epidemiology; therapeutics; new diagnostic tools.

All papers in Parasite are published in English. Manuscripts should have a broad interest and must not have been published or submitted elsewhere. No limit is imposed on the length of manuscripts.

Parasite (open-access) continues Parasite (print and online editions, 1994-2012) and Annales de Parasitologie Humaine et Comparée (1923-1993) and is the official journal of the Société Française de Parasitologie. 